\title{
ПЕРСПЕКТИВА КАО ИНТЕГРАЦИОНО СРЕДИШТЕ ИНТЕРПРЕТАЦИЈЕ РОМАНА ДОН КИХОТ МИГЕЛА ДЕ СЕРВАНТЕСА У МОДЕЛУ ИНТЕГРАТИВНЕ НАСТАВЕ ${ }^{1}$
}

\author{
поводом 400 година од смрти М. де Саведре Сервантеса
}

(I час, обрада)

\begin{abstract}
АПСТРАКТ
У овом раду дат је модел наставне интерпретације Сервантесовог романа Дон Кихот у контексту интегративног приступа. Предложени модел, као полазиште и чинилац обједињавања, за први час наставног рада на роману користи перспективу, после чега се прелази на испитивање основних елемената поетике барока, као и наративне форме (аутор, приповедач, приповедачи-посредници, нађени рукописи и сл.). Стога, основни циљ рада је расветљавање оних елемената структуре и значења романа чијим кумулативним садејством се остварује интензивирање уметничких доживљаја током наставног рада на роману, односно демонстрира један вид функционализације динамичке интерпретације романа с обзиром на поетику барока као доминирајући поетички дискурс.
\end{abstract}

Кључне речи: перспектива, роман, поетика барока, интеграциони чиниоци, наставна интерпретација, нарација.

1 Посебну захвалност при изради овог рада дугујем покојном проф. Пери Мужијевићу, који ме је мотивисао за изучавање ове епохе, откривши својим студентима, на незаборавним часовима Светске књижевности, један сасвим нови свет и једну културу необичног концепта, а непрозирну без оних сазнања која су неопходна да би се она правилно разумела. Захвалност, такође, изражавам и проф. др Мирки Зоговић на поузданим информацијама о књижевности барока, као и на одличном преводу релевантних фрагмената с италијанског језика, из до сада, нажалост, и даље непреведених капиталних дела, који се у раду наводе онако како их је она превела и у складу с њеним тумачењем. 


\title{
PERSPECTIVE AS AN INTEGRATING INTERPRETATION CENTRE - "DON QUIXOTE” BY MIGUEL DE CERVANTES IN THE MODEL OF INTEGRATED TEACHING
}

\begin{abstract}
This paper reveals a new model of teaching interpretation of the novel Don Quixote by Cervantes in the context of the integrative approach. The model proposed here, as a starting point and a factor of integration during the first teaching lesson/unit on novel uses the perspective. After that, it continues with the research of the basic elements of baroque poetics and narrative form (author, storyteller, storytellers-mediators, discovered manuscripts etc.). The main aim of the paper is to shed light on those elements of the structure and meaning of the novel whose cumulative interplay achieves intensification of artistic impressions. In other words, it demonstrates one aspect of teaching interpretation of this novel, according to the baroque poetics as dominant poetic discourse.
\end{abstract}

Key words: perspective, novel, poetics of baroque, factors of integration, teaching interpretation, narration.

\section{1. ИНТЕГРАТИВНИ ПОТЕНЦИЈАЛ ПЕРСПЕКТИВЕ КАО ИСХОДИШТЕ ИНТЕГРАТИВНЕ НАСТАВЕ}

Савремена наставна интерпретација, у доба „глобалног села“, умрежавања и хиперпродукције чињеница, неминовно је усмерена ка потреби за повезивањем наставе књижевности с предметом проучавања других наука. Та потреба конкретизује се, даље, као подробно разматрање „могућности програмског усклађивања наставе књижевности кроз доживљајно и сазнајно прожимање духовности процесуалне форме хуманистичких, друштвених и природних научних гледишта развијених у досадашњој предметној настави“ (Голијанин Елез 2014: 110). Будући да је роман Дон Кихот чврсто укорењен у поетичким, филозофским, политичким, научним и другим дискурсима времена у коме је настајао, једна методологија и једна интерпретативна и наставна парадигма не показују се довољним да представе макар главне концепте, на којима се и темељи свеукупна значењска структура романа. Отвореност ка различитим интерпретативним праксама, стога, постаје неминовност савремене наставе. Само тако је могуће уочавати везе које граде хомологију структура, како у свету који 
ученик прима као спознајни тоталитет тако и у књижевности као другостепеном моделативном систему.

Наставна и научна методологија, самим тим, нису и не смеју бити априорно дате, већ бивају условљене природом и карактером дела, пре свега везама које оно успоставља с литерарном традицијом, али и свеукупним изворима сазнања у времену када је оно настајало, а у контексту савремених увида. ${ }^{2}$ Самим тим, „примена интегралних методолошких поступака и актуелизација истраживачких гледишта усклађује се са природом и имплицитном поетиком уметничког дела. Методе интерпретације у новом кључу (критериј литерарности / жанровска припадност, књижевни код, унутрашњи хоризонт и спољашњи хоризонт / текстовне и вантекстовне појединости) дају веће могућности свеобухватног моделативног повезивања чињеница и стицања [...] знања ученика“" (Исто). Интегративни приступ овом роману најпре, повезује различите дисциплине (слично корелацијскоинтеграцијском наставном систему, само комплексније) и открива значајне (а неискориштене) могућности које припадају сазнајним сферама различитих друштвено-хуманистичких наука. Чињенице и увиди различитих наука (наука о књижевности, историја, философија/етика, историја уметности, теологија и сл.) тек у свом комплементарном садејству водиле би ка потпунијем разумевању структуре и значења овог романа, што, опет, захтева вишестраног и, пре свега, добро обавештеног наставника.

Уз то, када је реч о вантекстовним, а нарочито унутартекстовним везама између појединих елемената дела ,процене интегративних потенцијала књижевних текстова новијим теоријским приступима померају се ка иманентним везама јединства, које се у настави језика и књижевности најчешће откривају аналогијом и сталним метаморфозама типова исказа, значењских структура и моделативних система.“ (Исто: 115). То би значило да би „доминантни вредносни чиниоци дела [...] постали асоцијативна поља и интеграциона средишта и за многе друге знаковне вредности, па би се преко њих обезбедио истовремени увид у више естетичких чињеница које увек заједно и истодобно побуђују уметничке доживљаје, слободнији ток истраживачке пажње и сазнајних асоцијација“ (Исто: 26). Поменуте доминантне структурне и вредносне елементе дела Милија Николић назива чиниоцима обједињавања (в. 2009: 217-230) и даје неке моделе како се из перспективе једног (или више њих) може остварити наставна интерпретација која би

2 „Принцип интегративне наставе заснива се на методолошкој интегралности и интертекстуалности књижевних гледишта - од наставног проучавања књижевног текста ка стваралачком усвајању књижевнотеоријских појмова“ (Голијанин Елез 2014: 110). 
показала њихово кумулативно садејство и водила ка остваривању ефеката потпуније смисаоне заокружености и естетске сугестивности дела.

Конкретно, у интегративни фокус приступа овом роману током првог наставног часа постављена је перспектива, односно како поетика епохе барока и форме нарације (аутор, приповедач, приповедачи-посредници, казивачи, рефлектори, нађени списи и сл.) конституишу полифони барокни дискурс романа - комплесно вишегласје, настало као резултат ауторовог ingeniuma. На то би се надовезивало наставно тумачење различитих жанровских исходишта дела (насталих у плодотворном прожимању хронотопа витешког и пикарског романа, откривање функције и значаја инкорпорираних новела у роману; уочавање елемената других романескних жанрова - сентименталистичког и пасторалног - тј. како они функционишу у контексту овог романа), односно елемената композиције (други наставни час). Коначно, јунак (карактерологија, етички коิд, његова способност идеализације, концепт оштроумља, лудост као позиција за откривање истине и др.), идејни аспекти и разматрање елемената барокног стила (доминантног дискурса у стваралачкој концептуализацији романа) постају предмет интересовања током трећег наставног часа (синтезе), односно они вредносни чиниоци који, у узајамном прожимању с осталима, могу послужити као полазиште наставне интерпретације романа.

\section{1. ДОН КИХОТ У ПРОГРАМСКОМ КОНТЕКСТУ}

Сервантесов Дон Kuхот, први модерни роман европске књижевности, насупрот томе, у оквиру програмских садржаја српског језика и књижевности поприлично је маргинализован. Наиме, предвиђен је за наставни рад на одломку у првом разреду гимназије, заједно с другим репрезентативним делима, у оквиру епохе хуманизма и ренесансе. ${ }^{3}$ Ауторке Заводових Читанки (најчешће коришћеног уџбеника), сходно Програму, тако и поступају, опредељујући се за епизоду са ветрењачама као репрезентативни одломак (в. Николић и Милић 2008: 220-224) и тумачећи је у (релативно произвољно постављеном, а од дела у великој мери независном) типско-симболичком коду. ${ }^{4}$

3 За ова дела издвојено је 12 школских часова - в. Српски језик и кюижевност, I разред, приступљено 20. 2. 2016. URL: <http://www.zuov.gov.rs/dokumenta/CRPU/Programi\%20za\%20 gimnaziju\%20PDF/01\%20srpski\% 20jezik\%20i\%20knjizevnost.pdf>

4 У читанкама за 1. разред Љиљане Николић и Босиљке Милић одабрана је епизода из осме главе првог дела романа, која говори „о добром успеху који је имао храбри витез Дон Кихот у страховитом и нигда незамишљеном збитију с ветрењачама“ (2008: 220-223). Управо 
Овакво поступање твораца није најсрећније, будући да предложени поступак обраде одломка ствара неадекватне или чак погрешне представе о значењској структури романа у целости. ${ }^{5}$ Свођење овог ремек-дела на одломак (колико год он био сретно одабран) неће и не може надоместити сву сложеност релација које ово дело остварује унутар себе, као ни бројност интертекстовних веза, које успоставља с књижевним стваралаштвом које је претходило његовом појављивању - ма како успешно била остварена локализација датог одломка. ${ }^{6}$ Један од аргумената у прилог наставној

ова епизода парадигматична је за роман у целости и један је од херменеутичких кључева за тумачење дела (али, исто тако, служи и као основ за неоправдана уопштавања и значењске симплификације идејног плана романа), с тим што се дати одломак налази се у оквиру епохе хуманизма и ренесансе.

5 У том (секундарно генерисаном романтичарском) симболичком оквиру, борба јунака с ветрењачама у методичкој литератури сведена је на болне сукобе с различитим животним препрекама, а призвана у фази стварања проблемске ситуације следећим кључним речима, синтагмама и тезама: „sanjar na realnome tlu (snovi i stvarnost); uzaludnost zamisli o mijenjanju svijeta; slamanje iluzija, snova i ideala na realnome tlu; snovi i iluzije nisu potrebni u realnom svijetu“ (Rosandić 2005: 594 - истакао Д. Р.), који се радијално шири и повезује са другим призорима у роману који подржавају такву интерпретацију (уп. Исто). Но, овај одломак, у контексту дела, најављује, пре свега, сазнајни проблем: „The point of an encounter souch as an episode of the windmills [...] is that our knowledge cannot be grounded any more deeply (or, if the image is that of transcendence, any more highly) than our human practices. When faced with a character like Don Quijote, whose epistemological identifications differ so radically from those of the others in a novel, we discover that the world [...] is what we make it [...] Indeed, given the objects and situations over which Don Quiote and the other characters disagree, there is no way to formulate fhe difference between them except in terms of value, judgement, and, as I shall say, criteria.“ (Cascardi 1987: 168). Саодносно томе, хидалгова померена логика функционише на следећи начин: „Don Quijote is missing a certain piece of information, when in fact he is missing something like a piece of the world. When Don Quijote tells Sancho that he lacks familiarity with the adventures of knights-errant, he is in fact telling him that they do not share the same world: not sharing the same world, they do not share a common ground for making evaluations; they do not share the same values." (Исто 169 - истакао Д. П.). Стога, евидентно је да ниједан одломак, ма колико репрезентативан био, не може довољно добро одразити ово дело у целости нити представити главног јунака у свој комплексности, будући да се лик развија кумулативно - прогресијом догађаја које прати акумулирање искустава и сазнања која мудри Манчанац стиче.

6 Локализовању помињаног одломка често се приступа олако - само удовољавајући елементарним захтевима уже локализације, без дубљег понирања у дух времена у коме је дело настало, поетичке постулате жанровских форми из којих дело израста или моралне дилеме тог времена (шира локализација): „Riječ je о epizodi koja je naslovljena sintagmom borba s vjetrenjačama. Epizoda se lokalizira u fabulu romana (unutarnja lokalizacija). Ostvaruje se usmeno (to će učiniti učitelj/učiteljica ili učenik/učenica koji su pročitali roman)“ (Rosandić 2005: 592). Друга могућност коју овај аутор предвиђа је - израдом плана текста: „Ерizoda se može lokalizirati i popisom epizoda prema sižejnoj osnovi romana“(Исто). 
интерпретацији одломка (уместо дела у целости) ${ }^{7}$ могао би бити да поетичка и семантичка комплексност романа превазилази читалачко искуство ученика првог разреда средње школе. ${ }^{8}$ Но, питање да ли и у којој мери смисаоно богатство посматраног дела надилази узрасне и интелектуалне способности ученика првог разреда средње школе беспредметно је - идеални читалац (био он и неки признати сервантиста) не постоји (уп. Eko 2001), ${ }^{9}$ као ни „право“, или „коначно“ читање овог дела. У различитим читањима - од анализа појединих (микро)елемената дела, све до синтеза глобалног типа (в. Павловић-Самуровић 2005), без обзира на њихове претензије, само су одређени елементи дела читалачки актуализовани. Исто тако, и када су читаоци - ученици првог разреда, одређена истраживања несумњиво су показала „da su učenici na izvjestan način, uz pomoć nastavnika, uspjeli da svoju misao usmjere i da se prema romanu Don Kihot odrede“" (Božović 1977: 46).

Штавише, чињеница да се почетком XXI века у Шпанији појављују специјализоване, приређене верзије овог романа, намењене различитим узрастима, „почев од 4 године па навише“ (Павловић-Самуровић 2005: 1075), при чему се с интегралним текстом романа, у одговарајућој критичкој апаратури, сусрећу дванаестогодишњаци ${ }^{10}$ показује да су различити значењски кодови овог романа отворени - и за млађе узрасте. Према томе, аргумент о (не)примерености узрасту могао би се одбацити. Ако Дон Кихота у Шпанији читају дванаестогодишњаци, свакако ће га, на себи својствен начин, могу разумети и наши петнаестогодишњаци. Сваки ученик ће декодирати семантичко поље романа саодносно својим сазнајним могућностима.

Пошто су дела која су се нашла у наставним програмима преузета из канона највреднијих дела светске (и српске) књижевности, требало би опрезније поступати. Отуда, требало би, најпре, преиспитати најпре ваљаност, као и наставну и научну заснованост тренутно важећих планова

7 Основна аргументација методичара који заговарају став о наставном раду на одломку је та да би се, одабиром репрезентативног одломка, а потом и поузданом (широм и ужом) локализацијом романа, недостаци оваквог избора, донекле, умањили. Међутим, уместо тога, у наставној пракси, неретко се наставном проучавању датог одломка приступа као обавези, уз давање основних информација о делу, времену и писцу, или се одломак, чак, уопште не ради. 8 Стога, зарад „,usklađivanja kodova (čitateljskoga i koda književnoga djela),“ Д. Росандић (2005: 595), препоручује позивање на она дела, посредством којих се актуелизују „vlastita iskustva, doživljaji i razmišljanja“(Исто) ученика.

9 Одређена тумачења која су понудили неки сервантисти - универзитетски професори, била су предмет оштре критике (уп. Павловић-Самуровић 2005: 1079) и остала отворена за нове (ре)интерпретације.

10 „За децу почев од 12 година предвиђен је коментарисан интегрални текст или антологије састављене од најпознатијих поглавља романа.“ (Павловић-Самуровић 2005: 1076). 
и програма - посебно - место овог дела у њима, а потом и њихову примереност савременом ученику као читаоцу. Уколико је роман некада рађен у целости (в. Božović 1977: 41), на више часова (барем три - Исто), није јасно зашто се у актуелним програмима поступа другачије и он бива сведен на одломак, попут неких естетски мање успелих остварења. ${ }^{11}$ Стога, предлог наставног рада на роману (у целости), када је о овом делу реч, намеће се као методичка неминовност, а простор за то могао би се наћи правилнијим поетичким ситуирањем дела - у оквире епохе барока. ${ }^{12}$

Уместо тога, Сервантесово ремек-дело у програму првог разреда уврштено је у избор из дела у оквиру епохе хуманизма и ренесансе, што, наравно, није добро будући да је дело стварано на доминантно барокној поетичкој парадигми - током златног века шпанске књижевности, као што ће бити показано у овом раду применом интегративног приступа. Томе у прилог сведоче не само временске референце, већ и интертекстуалне (пародија - пародирано) и паратекстуалне везе с другим делима (и жанровским формама) тог времена, његова комуникативност, сложеност и слојевитост структуре, начин оркестрације, метатекстовни (полемички) карактер дела (нпр. расправа о томе да ли треба предност дати науци или opyжјy - armas y letras и сл.), као што ће у даљем раду бити показано. ${ }^{13}$

Пре почетка наставног рада на роману неопходно је адекватно мотивисати ученике, ${ }^{14}$ благовремено их припремити за читање дела и на време

11 Поређења ради, за наставни рад на одабраним одломцима у првом разреду средње школе предвиђен је спев Осман Ивана Гундулића - дело стилски, композиционо и естетски неуједначено, а уврштено у програм вероватно на основу критеријума репрезентативности.

12 Конкретно, за епохе барока и класицизма (7 наставних часова), предвиђени су (само) следећи садржаји: Барок и класицизам и ғихови главни представнищи у Европи и код нас; И. Гундулић: Осман (одломци из I и VIII певања) и Молијер: Тврдица (в. Програм, І разред), што, очито, оставља довољно простора за три наставна часа, предвиђена у овом раду за разматрано дело.

13 У актуелним студијама више нема недоумица око временског и поетичког одређења дела: „Тако ће, почетком 17. века, у тренутку који већ припада барокном добу, у споју обнове једног старог жанра и пародијског односа према њему, настати ремек-дело Мигела де Сервантеса.“ (Попов 2012: 89, истакао Д. П.).

14 Дело је, дакако, отворено за различите мотивационе поступке. Како се, приликом читања, ангажују различите доживљајне и сазнајне категорије и различити нивои (рецепцијски, аналитички, стваралачки), тематизовање кризе система вредности (приказано у различитим доменима у роману) намеће се, као заједнички именитељ и показује погодним за мотивациони разговор којим ће се дело „отворити“ подједнако за емоције и искуство ученика - од свакодневних животних ситуација, које ће ангажовати њихово запажање и мишљење, преко читалачког искуства, све до изналажења универзалности ставова, процена, мисли, идеја и животних истина које дело открива. 
усмерити ка његовим доминантним вредносним чиниоцима, а догађање дела на часу (у смислу естетског и сазнајног појачавања и продубљивања) омогућити пажљиво осмишљеним припремним истраживачким задацима (в. Прилог 1).

\section{2. ПОЕТИКА. ОТКРИЋЕ ПЕРСПЕКТИВЕ}

Већ на прво читање, Сервантесов роман оставља утисак извесне условљености духовном атмосфером времена у коме је настао. Дело је тим интересантније што се појављује када је барокна поетика - на нивоу теоријских уопштавања - недовољно неконституисана, ${ }^{15}$ али препознатљива jep је у књижевности већ дала значајне представнике, а поетика хуманизма и ренесансе у завршној фази. Таква поетичка и стилска двојност манифестује се не само у концепцији Дон Кихотовог лика - барокног оштроумног лудака ${ }^{16}$ који заговара и брани хуманистичке вредности - већ и дела у целости: „Opšta tendencija knjige, sa njenim epistemološkim pitanjima i psihološkim suptilnostima, otkriva vreme mnogo složenije nego što je to bila renesansa.“ (Brenan 1970: 190). У компаративном контексту посматрано, може се приметити да је, „Don Quiote [...] nastao, slično Montenjevim Esejima sa poslednjim talasom humanističkih osećanja i vrednosti. Ipak, u njemu ima osobenosti XVII veka. Sam njegov junak pripada silovitom, sanjalačkom svetu barokne hagiografije." (Исто).

У овом роману основни обликотворни поступак уједно је и један од основних поетичких постулата барока (присутан у различитим уметностима): повезивање удаљених појмова, тзв. сйајање несйојивоі; дају се једна уз другу две стварности - реална и идеална, или, жанровски посматрано, свет витешког романа и свет пикарског романа. Наравно, ова два света кореспондирају посредством ликова, тако да се у прекидној структури светова и времена неосетно прелази из једног у други, било Дон Кихотовом идеализацијом “објективне” (тј. књижевноуметничке) стварности или читавим мини-сценаријима (обично, грубим шалама), које други ликови припремају као својеврсну уроту - свесним претварањем и играњем своје

15 Најзначајнији програмски текстови барокне поетике Емануела Тезаура, Матеа Перегринија и Валтазара Грасијана појавиће се касније, када је барокно стварање на силазној путањи.

16 Спајање удаљених или неспојивих ствари, промишљање каузалитета односа у свету на нов, неочекиван и необичан начин јесу они постулати барокне поетике на којима је креиран овај лик - "El Ingenioso Hidalgo" јесте такав и тако функционише - његови увиди јединствени су, а понекад се чине истинитијим и стварнијим од оних које, конвенционално, деле остали. 
улоге у посебно креираном свету који Дон Кихот држи за једини стварни свету витешког романа.

Необични начин приказивања стварности, попут овог, канонизован је касније, у барокним поетикама, за пожељни модус стварања. Наћи сличност у несличном и уз то, по могућности укључити и “неки други састојак, као на пример: тајну, контраст, сразмер, несразмер, сентенцу“17, све оно чега иначе има у овом роману, инвентивно и домишљато укомпоновано, постаје касније, када се код барокних стваралаца јави потребна мера артистичке самосвести, једна врста стваралачкога императива. ${ }^{18}$. С обзиром на то, читава оркестрација романа може се посматрати као својеврсни кончето, ${ }^{19}$ заснован на игри перспектива, док ће у наставној интерпретацији романа управо перспектива бити онај интеграциони чинилац који ће, ученике, претходно мотивисане за читање романа и усмерене адекватним припремним задацима - од радно-инструктивног типа, до оних који су усмерени ка ангажовању стваралачког мишљења ученика, увести ученике у наставну интерпретацију дела.

17 УП. Gracián, 1986. Сви цитати у даљем раду наводе се према преводу Мирке Зоговић.

18 Тек ако је нешто оштроумно приказано, оно има право на постојање и може да живи, или као што то формулише Грасијан, када је, "поред реторичке вештине присутна и кончетозна“ (Исто). Сличне формулације се, готово као варијација, јављају и код трећег језуите теоретичара барока, Емануела Тезаура: „У ствари, онолико је нешто мртво колико није акуменом оживљено“ (Tesauro 1960 - нав. према преводу М. Зоговић).

19 Кончето је у различитим интерпретацијама добијао најразличитија значења. Rečnik književnih termina (1985) предлаже следећа решења: појам, замисао, идеја. Указује, такође, и на значење кончета у смислу умећа изналажења сличности између предмета и појава, наизглед потпуно различитих (в. RKT 1985, s.v.). У одредници је вреднован готово негативно, као инсистирање на "исфорсираним и бизарним поређењима“" (Исто). Међутим, барокни теоретичари су овај појам одређивали знатно флексибилније. Ернст Роберт Курцијус наводи два кључна дела барокне провинијенције - Delle acutezze, che altrimenti spiriti, vivezze, e concetti volgarmente si apelano... trattato Матеа Перегринија, где се већ у наслову одређује појам кончета: Трактат... о пронищьивостима које се иначе просто називају и довитьивости, живости и концепти (1996: 480). Овде се кончето (concetto) схвата поприлично широко и заправо изједначава се с оштроумљем (acutezza), тј. проницљивошћу (како је то, премда не најбоље, решено у преводу Курцијусове књиге) Друга значајна књига је дело Балтазара Грасијана Agudeza y Arte de Ingenio, en que se explican todos los modos y diferencias de Conceptos, тj. Пронищьивост (sic!) и вештина духовитости којом се објашъавају све врсте разлика y концептима. Курцијус под кончетом подразумева различита значења попут: конщепт, мисаона садржина, појам, оштроумност (на основу чега се може приметити да се значење овог термина преплиће са значењем појмова acumen и acutezza), а понајчешће га одређује као мисаону садржину (Исто: 479-493). Схвата га, такође, и као низ правила за стварање силогизма (Исто: 487). То наводи на закључак да ни Курцијус, заправо, нема коначну дефиницију кончета, баш као што је нису имали ни аутори барокних поетика. 
Најчешће се у теорији књижевности перспектива одређује (само) с наратолошког аспекта (RKT 1985, s. v. перспектива), и изједначена је с тачком гледишта. У барокној књижевности, овај појам схваћен је шире, као у ликовној уметности, али и поетичким и философским трактатима. Како је, у предложеном моделу наставне интерпретације, овај појам/поступак узет као чинилац обједињавања, неопходно је читање засновано на прожимању и корелацијско-интеграцијском повезивању сфера сазнања философије, књижевности и других уметности. Зато ће перспектива укључити и значења промене устаљеног начина посматрања, онеобичавања, заузимања сопствене тачке гледишта, а што је, уједно, и начело којим се води главни лик романа.

Стога, перспектива је одређена у контексту поетике барока, премда дело, тематски и идејно, отвара и одређене хуманистичке проблеме (о чему ће касније бити речи). Тиме се семантичко поље овог појма нужно шири и помера с (рестриктивног) схватања перспективе - позиције приповедача у односу на текст, тј. да ли је приповедач телесно присутан (унутрашња перспектива - тачка гледишта у самој причи, варијантно - улога рефлектора) или одсутан (спољашња перспектива - тачка гледишта изван приче) на аспекат жанра, карактерологије, поетике, стила... Х. Хацфелд уочава перспективизам и на нивоу композиције, односно говори о барокној композицији романа полазећи од жанра:

Књижевни облик, упркос модерних покушаја изједначавања епског, лирског и драмског (Кроче) и упркос теорије драге некима који кажу да 'Кихот'као и 'Селестина'не пристају ни у један књижевни оквир, у очима критичара тумача појављује се као један тип романсијерске композичије коју је песник нашао историјски развијену у витешким романима, а коју, упркос својој пародији, формално наставља. [...] Композииија показује тежњу ка јединствености епизода и структуру према дубини. Тако открива композицију која се од Х. Велфлина назива "барокном" и одатле се намеће питање разлога свега тога; решење је било историјско и налазило се у основи барока - у Контрареформи. (Hatzfeld, нав. према: Павловић-Самуровић 1982: 88).

Откривање перспективизма, као и поигравање перспективама, представљају аутентичну црту барокног израза. И Сервантес је, дакако, користи, с тим што он у свом експериментисању долази до сложене наративне форме, настале као резултат семантичке напетости кодова (дискурса, 
жанрова, хронотопа...). ${ }^{20}$ Оно што генерише ту напетост у делу је - сам Дон Кихот, односно његов специфични перспективизам, заснован на способности да од крчме види дворац, у ветрењачама - дивове, а у стаду оваца - непријатељску војску: „Situations like these form the basis for what Ortega y Gaset and Leo Spitzer have called 'Cervantes' perspectivism,' that discrepancy of awareness by virtue of which objects and events seem to be one thing for Don Quijote and something quite different for Sancho and the other characters in the book." (Cascardi 1987: 165). Њега не би требало, међутим, сводити на релацију здраворазумске позиције (други ликови) и лудости (главни лик), односно несклада између две перцепције света, будући да перспективизам сеже све до етичке димензије дела: ,What is immediately striking about Cervantes' perspectivism, however, is that it is not a strictly epistemological problem but involves important questions of value as well“" (Исто). ${ }^{21}$

Ученицима ће бити приказана (путем пројектора, смарт-табле и сл.) уметничка слика Дијега Веласкеза Mладе племкиње (Las Meniñas) ${ }^{22}$ како би им се (у складу с принципом очигледности) приближио перспективизам, у значењу (промене) тачке гледишта. Притом, у први план се истиче структурирање света - по принципу огледалског пресликавања стварности; 23 уочава се позиција уметника оквиру композиције, дубински план, стил детаљизације, тежња ка истинитости приказивања... Истичу се, такође, аналогије између платна и Сервантесовог дела у погледу начина

20 Литерарни утицаји бројни су и разнолики, тако да роман успоставља мрежу интертекстовних релација у односу на традицију:

Речено grosso modo, Сервантесова уметност је синтеза. Његов идиоматски реализам потиче великим делом из Селестине, његова антитеза из Витеза Сифара; његово сликање и дескрипиије личности из Дијане Хорхеа де Монтемајора и из дијалога Хуана де Валдеса; дескрипиија обичаја из пикарског романа; тон његовог витеза луталице из Амадиса и из Палмерина; лингвистички идеал своје сопствене речи следи идеал Фра Хосеа де Сигуенсе у юеговој веома изворној Историји реда Светог Јеронима. Ритмичка форма фразе склопљене ичиероновски која мења динамичку приповедну прозу на толико места у крајюој линији потиче од Бокача [...] Сервантес се показује као истински изумитељ постренесансне уметности. (Hatzfeld, нав. према: ПавловићСамуровић 1982: 76).

Па ипак, синтетичка форма, дата у виду пародије витешког романа, у коме су интегрисани међусобно различити, понекад и неспојиви дискурси, резултат је искључиво Сервантесовог ingeniuma.

21 О Дон Кихотовој етичкој перспективи, везаној за пројекат обнове пољуљаног система вредности у свету, биће више речи на 3. часу, приликом наставног тумачења главног лика.

22 В. Прилог 2.

23 Ученици се, притом, подсећају на значење појма mimesis, усвојено на уводном часу у епоху хуманизма и ренесансе. 
уношења ствараоца у свет дела, што, уједно, служи као везивни елеменат који повезује ову са следећом наставном ситуацијом - формама нарације.

\section{3. ПЕРСПЕКТИВА НАРАТОРА И ПОСРЕДОВАҢА У НАРАЦИЈИ}

Облици приповедања представљају један од типичних чинилаца обједињавања у наставној интерпретацији прозних дела (в. Николић 2009: 223-224). Теоријско и наставно проучавање (типова) нарације у роману Дон Kuxom најпре изискује поређење са стваралаштвом романописаца пре Сервантеса. Његов роман постао је први модерни европски роман, што указује на то да дело представља значајан искорак из традиције. Век пре њега појавио се значајни Раблеов роман Гаргантуа и Пантагруел са којим је Рабле препознат као први велики сатиричар модерне европске књижевности. Сервантесов роман, заједно с овим романом, представља уједно и прво веће експериментисање са структуром романа.

Мењање перспективе аутора (спољашња/унутрашња) и композиционо усложњавање структуре романа (што постоји и код Раблеа) Сервантес доводи до маестралности. Притом, један од основних поступака који он користи је да ликове из романа премешта у “реални” свет, односно у своју свакодневицу. Исто тако, он читаоца посматрача (заправо, улогу коју писац неосетно гради, а читалац прећутно прихвата) ${ }^{24}$ уводи у свет дела, односно поставља га у егзистенцијалну позицију ликова.

Као основна теоријска парадигма за испитивање нарације у овом роману, коришћени су радови немачких теоретичара нарације - Франца Штанцла (1987) ${ }^{25}$ и Волфганга Кајзера (1991: 509-520). Иако међусобно полемички оријентисани, они, ипак, указују на мноштво релација, остварено између два света. Док Штанцл одређује основне типове приповедачких ситуација (с обзиром на модус приповедања, персону и перспективу), Кајзер (и поред тога што не уочава трећи тип тзв. приповедачких ситуација) даје суптилну анализу текстовних чињеница, бавећи се аутором и читаоцем као учесницима у комуникацији и од нарације као формалног момента долази

24 Због те наративне стратегије Дон Кихот (углавном у II књизи) понаша се као да наступа пред публиком.

25 Са Штанцловим појмовима аукторијалног и персоналног приповедања, приповедања у првом и трећем лицу, као и категоријама модуса, персоне и перспективе ученици се могу факултативно упознати раније, рецимо приликом наставног рада на приповеци Први пут с оцем на јутрење Л. Лазаревића, када ће им бити подељен и табеларни преглед ових категорија с обзиром на позицију наратора. 
и до егзистенцијалне ситуације наратора где се нејединственост и двојност приповедачког Ја и доживљајног $\mathrm{Ja}^{26}$ проблематизује до метафизичке запитаности “Ко сам ја“. Сличан тип подвојености главног лика „између Алонса Кихана с надимком Добри и Дон Кихота запажа се и у овом роману.

Највећа предност Штанцлове студије је у успостављању разлике између тзв. "аукторијалне приповедачке ситуације“ (овај тип нарације обично се препознаје као перспектива свезнајућег наратора ${ }^{27}$ ) и "романа у првом лицу“" (приповедач се налази на егзистенцијалној позицији ликова, чиме је сазнајно ограничен). Други тип нарације уједно је основни начин повезивања новела у роману и основне линије фабуле (што ће бити предмет посебног поглавља). Примера ради, меморат заробљеног шпанског капетана (присећање епизодног лика на догађај из прошлости) директно уводи аутора романа у свет дела. Ту овај лик говори о Сервантесу о као свом сапатнику у заробљеништву, хвалећи његову храброст, одважност и пожртвовање, и поред изузетно тешких прилика у којима су се нашли и свирепости Турчина у чијем су заробљеништву били:

Једини је са њим излазио накрај један шпански војник, неки Саведра, који иако је учинио ствари које ће код оних људи остати дуге године у памети, а све да би дошао до слободе, ипак га никад не удари, нити заповеди да га бију, нити му ружну реч рече, а за најмању ствар од оних многих што их је учинио ми смо стрепели сви да ће га набити на колаи, а сам је то очекивао не једанпут; и кад бих само имао кад, бих вам сада причао што од онога што је тај војник чинио, и то би вас много већма занимало и ви бисте се далеко више чудили него мојој приповести.

(Сервантес 1999, књ. 2: 363-364 - истакао Д. П.). ${ }^{28}$

Лик овог капетана у наведеном одломку креће се у свету историјских личности, учествује у историјским догађајима - ратује, као заставник, у бици код Лепанта под командом капетана Дијега од Урбине (Исто: 355), под чијом се командом налазио и Сервантес, са којим је заробљен. ${ }^{29}$

26 Претходна два термина преузета су из Штанцлове терминологије, док их Кајзер не експлицира.

27 УП. RКТ 1985, s. v. tačka gledišta.

28 Сви даљи цитати наводе се према издању: Сервантес 1999.

29 Укрштање перспективе реалног света и света дела остварено је на сличан начин и на композицији Дијега Веласкеза Младе племкиње (Las Meniñas), као што је претходно речено (в. Прилог 2). Композиција припада репрезентативним делима шпанског барока, а с обзиром на 
Сличан искорак из света дела постоји у другом делу романа, када Дон Кихот, литерарно мотивисан (појављивањем Авељанединог Дон Кихота, у коме он бива деградиран до мономана и карикатуре) креће у одбрану сопствене аутентичности и, између осталог, присиљава Дон Алвара (лик из Авељанединог романа) да потпише изјаву пред судом „како није познавао Дон Кихота од Манче, који је такође ту присутан, и да то није онај који је штампан у једној повести под насловом Други део Дон Кихота од Манче, сачињен неким Авељанедом, родом од Тордесиља" (Исто: 501). Слична ситуација појављује се нешто раније, када Дон Кихот, у једној штампарији у Барселони, затиче словослагаче како припремају за штампање Авељанедин Други део Дон Кихота (Исто: 448). На поступку разбијања артифицијелног карактера дела задржава се и В. Шкловски, повезујући овај поступак с позоришном техником „пробијања рампе“, тј. разбијања илузије театра. ${ }^{30}$

Нарација је и у првом делу романа вишеструко посредована и усложњена. ${ }^{31}$ Причу почиње писац - аутор првих девет глава романа, док Сервантес себи намењује улогу приређивача рукописа и коментатора, заинтригираног необичном повешћу. Први аутор оставља причу на најинтересантнијем

то да сликар, у огледалској перспективи, приказује и себе како слика овај групни портрет, дело би, у контексту интегрисане наставе, могло послужити као херменеутички кључ за наставну интерпретацију (перспективе, нарације и неких поетичких питања) Сервантесовог романа. Репродукција слике или URL адреса дају се ученицима, заједно с истраживачким задацима, пре почетка наставног рада на роману, а пројектује током овог часа.

30 Сличном поступку прибегавају и други, нпр. Б. Брехт, а Шкловски га уочава и у Шекспировом Краљу Лиру: „С̌ini mi se da ovde imamo ne osobito jako izraženo naglašavanje rampe, orijentaciju na uvjetnosti umjetnosti, njezino pedaliziranje. Tome tipu može se pribrojiti i izjava kralja Lira kad mu kćeri govore da mu je potrebno pedeset i više vitezova, a on se obraća publici, upire prstom u jednu elegantnu damu i pita 'Zar su njoj potrebne haljine da je griju' [...] Što se tiče kazališta, u njemu iluzija, najvjerojatnije, mora nositi nestalni, treptavi karakter, tj. čas da se pojavljuje, čas da nestane potpuno. Gledalac mora u sebi provjeravati smjenu percepcija scenske radnje jednom kao nešto 'namjerno', drugi put kao 'stvarno'.“ (Šklovski 1969: 94).

31 Како би се она, донекле, поједноставила, могуће је увести начелно разграничавање на нараторе који припадају фабули, односно сижеу, као и оне који излазе из сижејних оквира дела. Комплекснија наратолошка испитивања овог романа већ су спроведена - пре свега, „проучавана је мистификација са многобројним ауторима дела који се у њему помињу, а који се на веома сложен приповедачки начин смењују у функцији пишчеве намере да се иза њих прикрије““ (в. Павловић-Самуровић 2005: 1080). Зависно од методолошке оријентације, истицани су поједини наративни поступци. У својој синтези, „Монтеро Регера показује како су разни истраживачи тумачили функцију дијалога у Дон Кихоту, а како присутност више приповедача које Сервантес наизменично уводи у наративни ток; показује како је на тумачење овог шпанског романа примењена Бахтинова књижевна теорија, а како је наратологија, првенствено под утицајем Женета, у најновије време нашла своје место у сервантистичким истраживањима“ (уп. Исто: 1084). 
месту - усред сукоба „који су имали срчани Манчанац и храбри Бискајац“ (Сервантес, књ. 1: 63), а упорношћу аутора - приређивача, долази се до наставка необичне повести, игром случаја. Сервантес није сматрао потребним да детаљније образложи промену наратора. Приређивач дела губи наставак приче негде око почетка ове борбе, да би је касније нашао на пијаци, код продавца старе хартије, и то на арапском. ${ }^{32}$ Аутор-приређивач плаћа извесном Мориску да му текст преведе, чиме се уводи још један посредник у нарацији. Тако, од девете главе, наставља се Повест о Дон Кихоту од Манче (овог пута) списана Сид Аметом Бенениелијом, арапским повестописием, у чијем имену Сервантес (у облику калка) скрива своје име. Реконструисани ланац смењивања различитих наратора би, стога, имао овај след: ииисац-йриређивач - ирви ииссац (до девете главе) - иревоgилац - Cиg Амети Бененцелија. ${ }^{33}$ На ауторство такође претендује и Авељанеда, писац апокрифног Дон Кихота ${ }^{34}$. Да је писац остао индиферентан на Авељанедине жаоке и узурпацију ауторског права, не би било ни ове интересантне полифоније. Такође, ни Дон Кихот не би имао разлога да одлучно иступи у одбрану сопствене аутентичности. Он, међутим, развија стратегију чији је основни циљ да покаже лажност Авељанединог лика. Све време наступа под геслом „Ја нисам тај о коме та повест пише“ и зато и не иде на витешки турнир у Сарагосу, како је било назначено у првом делу Дон Кихота, где се обрео Авељанедин јунак. Уместо тога, он одлази у Барселону, не би ли тиме показао лажност супарника. Тиме овај роман и добија посве модеран, чак, постмодеран карактер - различити текстови и ликови успостављају интертекстовне везе и бране своје позиције.

Од полазне позиције свезнајућег приповедача нарација се постепено приближава нарацији у првом лицу: аутор-приређивач повести трага за другим делом повести о Дон Кихоту и у другом делу бива „увучен“ у свет свог дела, заузимајући исту егзистенцијалну позицију као и ликови (уп. Сервантес 1999, књ. 2: 38). Овакво укрштање и преплитање перспектива омогућава још једну ситуацију: Дон Кихот уноси дозу неповерења у веродостојност

32 Поступку одлагања разрешења прибегава се како би се читаоци заинтригирали за даљи ток фабуле романа.

33 Као потенцијални наратори јављају се још и ликови у новелама, који у форми мемората или фабулата износе неку „животну причу“, док као епизодни ликови учествују у главном току фабуле романа. Следом уочавања/ штафетног смењивања наратора, приповедачи се, када их ученици уоче и образложе, бележе на табли.

34 Дело је потписано именом лиценцијата Алонса Фернандеса Авељанеде. Ко се заправо крије под овим именом, науци је до данас остало непознато. Књига је изашла из штампе 1614, када је Сервантес имао написан већи део друге књиге Дон Кихота. 
приче свог повестописца: ,али га опет растужи помисао да му је писац био Мавар, по оном имену Сид, а од Мавара није се могла очекивати никаква истина, јер су сви варалице, кривотворци и занесењаци.“ (Исто: 28-29). ${ }^{35}$

Сансон Караско обавештава Дон Кихота о првој књизи, а посредством тог разговора у дело се уводе и неке од читалачких реакција на први део. Издвојиле су се примедбе у вези са слабом мотивацијом за увођење новела у главни ток романа:

Једна замерка коју праве повести, рече бакалореат у томе је ито је юен писаи у юу уметнуо новелу под насловом Неоирезни радозналац, не ито би била и рђаво написана, него ито јој није тамо место, нити је у каквој вези са повешћу милостивога господина Дон Кихота. (Исто: 33).

Тим критикама се придружује и Дон Кихот: „'Ја сада велим’, рече Дон Кихот, 'да писац моје повести није никакав мудрац, него нека незналица и брбљивац који се насумице и без свака промишљања дао у писање'.“ (Исто). Разочараност је тим већа јер је Дон Кихот све време очекивао идеалног биографа (уп. Сервантес 1999, књ. 1: 21), а добија повестописца Арапина, чију причу прати трајна сумња у њену поузданост. И аутор-приређивач заузима став сличан Дон Кихотовом, истичући да је основна врлина сваке књиге њена истинитост, за коју аутор не сме да гарантује у овом случају, инсистирајући тиме на артифицијелности поступка:

Ако би се могло ито приметити у погледу на њену истинитост, једино би било то ито јој је писац Арапин, јер том народу особито је својствено да лаже; но како су нам толики непријатељи, пре би се могло узети да је што умањио неголи да га је увеличао; и мени се баш тако чини; јер кад би могао и требало да развезе пером у хвалу тако ваљьана витеза, он као да хотимице то прећуткује. (Исто: 66).

Према томе, намерно инсистирање само на неуспешним Дон Кихотовим подухватима дало би се приписати Сид Амету. Оваквим (фингираним) отклоном постиже се стална динамика и дифузност дела, где је све приказано у покрету, расуто на све стране, тако да се композиција само уз напор

35 И само инсистирање на истинитости приповеданог својеврстан је разлог за неповерење: „the narrator himself is not trustworthy; the text is translated and edited account of the Arabic historian Cide Hamete Benengeli, whose repeated insistence on the veracity of his version should alone be reason enough for us to mistrust its every word" (Cascardi 1987: 166). 
посматрача (тј. читаоца) да̂ сагледати (уп. Велфлин 2000: 31). Стога, као карактеристична барокна црта би се и могла издвојити управо ова „општа промена форме која подједнако обухвата све уметности“ (Исто: 37). И то не само на формалном, већ и на садржинском плану: ни сам лик Дон Кихота није конзистентан јер је дат у низу преображаја.

У овом заузимању дистанце лика од дела у коме је оваплоћен огледа се пишчева изграђена поетичка самосвест, луцидност у одабиру (и функционалности) поступка, али, исто тако, омогућено му је и вишеструко маневрисање ликом. Дати поступак, осим вишеструке промене наративних перспектива, подржан је и другим елементима, попут датирања - уношењем актуалног времена (Санчово писмо Терези Панса датирано је 20. јула 1614.) или уношењем историјских елемената у роман. Ауторово интервенисање у Сид Аметов текст и његово заузимање дистанце уочава Љиљана Павловић Самуровић:

У структури сваког поглавља Сервантес је са великим мајсторством наизменично користио дијалог, монолог и дескрипцију. У ретким приликама, када му је било стало да се што више дистанцира од сопственог дела и да му да привид стварне историје, уносио је кратке одломке - коментаре које је писао не као аутор већ као приређивач дела, у којима је или објашњавао, или критиковао приповедачки поступак фиктивног Дон Кихойово̄ аутора Сид Амета. (ПавловићСамуровић 1982: 66).

Исто тако, на више места, он (привидно) препричава и сажима Сид Аметов текст.

Сид Амет, као улога, потенциран је на крају романа. Парох, Дон Кихотов пријатељ, на крају тражи још један доказ - да је Дон Кихот умро природном смрћу, штитећи тиме, уједно, Сервантесова ауторска права од будућих потенцијалних узурпација. Дон Кихота сахрањују, а Сансон Караско му пише епитаф. Финални глас припада Бененџелији: „Једино за ме родио се Дон Кихот и ја за њега; он је умео делати а ја писати“ (Сервантес 1999, књ. 2: 513). Утисак флуктуације, као и отпора фиктивног света плагијаторима из емпиријске стварности очит је. На фону таквих релација, успостављених између различитих стварности и различитих времена, развијају се и ликови: „Динамичка напетост излази на видело из чудних околности, због неког изненадног подстицаја и у узастопном живљењу личности установиће се 
повезаности онога што је већ садашњост са оним што ће јој се догодити."з6 Истовремено, овим напуштањем и поновним активирањем појединих наратора, као и експериментисањем с улогом наратора уопште, аутор, од формалног елемента романа, добија вишеструко функционално средство које роману обезбеђује трајну виталност и непоновљивост.

После аналитичког сагледавања различитих форми и типова нарације, ${ }^{37}$ трепераве полифоније и смене перспектива, њихове функционалности, али и поетичке задатости, током наставне интерпретације романа, ученици се, из наставне ситуације везане за облике приповедања, логичким каузалитетом, уводе у композицију, ликове, идејни план дела и елементе стила (на које су претходно усмерени одговарајућим истраживачким задацима).

Основна намера овог рада је испитивање перспективе и нарације као оних елемената који, у садејству с осталим, омогућавају аналитички продубљено сагледавање других елемената из перспективе одабраног интегративног чиниоца. На тај начин продубљује се уметнички доживљај, а истовремено, по принципу здружених кодова, интензивира се и утисак естетске заокружености дела. Стога, даље тумачење структуре и значења овог романа као уметничког артефакта у настави, на наредним часовима, осмишљено је као модел динамичке интерпретације, у контексту могућности интегративног приступа, а антиципирано перспективом и поетиком барока као доминирајућим поетичким дискурсом.

\section{ИЗВОРИ И ЛИТЕРАТУРА}

Велфлин, Х. (2000). Ренесанса и барок. Сремски Карловци, Нови Сад: Издавачка књижарница Зорана Стојановића. [Velflin, X. (2000). Renesansa $i$ barok. Sremski Karlovci, Novi Sad: Izdavačka knjižarnica Zorana Stojanovića.]

Голијанин Елез, С. (2014). Српски језик и књижевност у савременој стратегији развоја образовања. Сомбор: Педагошки факултет. [Golijanin Elez, S. (2014). Srpski jezik i književnost u savremenoj strategiji razvoja obrazovanja. Sombor: Pedagoški fakultet.]

36 Américo Castro, Hacia Cervantes, нав. према - Павловић-Самуровић 1982: 97.

37 „Облици казивања су средишне и водеће структуре књижевних дела и њихови врло динамични конституциони елементи“ (Николић 2009: 223), чиме постају захвалан интегративни чинилац који обезбеђује лак и природан прелазак на друге вредносне чиниоце дела. 
Илић, П. (2006). Српски језик и књижевност у наставној теорији и пракси. Нови Сад: Змај. [Ilić, Р. (2006). Srpski jezik i književnost u nastavnoj teoriji i praksi. Novi Sad: Zmaj.]

Кајзер, В. (1991). "Тко приповиједа роман", у Теоријска мисао о къижевности, прир. П. Милосављевић (Нови Сад: Светови): 509520. [Kajzer, V. (1991). "Tko pripovijeda roman", y Teorijska misao o književnosti, prir. P. Milosavljević (Novi Sad: Svetovi): 509-520.]

Курцијус, Е. Р. (1996). Европска књижевност и латински средњи век. Београд: Српска књижевна задруга. [Kurcijus, E. R. (1996). Evropska književnost i latinski srednji vek. Beograd: Srpska književna zadruga.]

Николић, Љ. и Б. Милић. (2008). Читанка са књижевнотеоријским појмовима: за I разред средње школе. Београд: Завод за уџбенике. [Nikolić, LJ. i B. Milić. (2008). Čitanka sa književnoteorijskim pojmovima: za I razred srednje škole. Beograd: Zavod za udžbenike.]

Николић, М. (2009). Методика наставе српског језика и књижевности. 5. допуњено издање. Београд: Завод за уџбенике. [Nikolić, M. (2009). Metodika nastave srpskog jezika i književnosti. 5. dopunjeno izdanje. Beograd: Zavod za udžbenike.]

Павловић-Самуровић, Љ. (1982). „Дон Кихот“ Мигела де Сервантеса. Београд: Завод за уџбенике и наставна средства. [Pavlović-Samurović, LJ. (1982). ,Don Kihot“ Migela de Servantesa. Beograd: Zavod za udžbenike i nastavna sredstva.]

Павловић-Самуровић Љ. (2005). “Сервантесов 'Дон Кихот” данас проучавање и вредновање“. Летопис Матище српске год. 181, књ. 476, св. 6: 1068-1089. [Pavlović-Samurović LJ. (2005). "Servantesov 'Don Kihot' danas - proučavanje i vrednovanje“. Letopis Matice srpske god. 181, knj. 476, sv. 6: 1068-1089.]

Попов, Ј. (2012). "Весници пародије: Бесни Орландо и Дон Кихот“, у Двобој као књижевни мотив: тематолошка студија (Нови Сад: Академска књига): 88-105. [Popov, J. (2012). "Vesnici parodije: Besni Orlando i Don Kihot", u Dvoboj kao književni motiv: tematološka studija (Novi Sad: Akademska knjiga): 88-105.]

Сервантес, М. де (1999). Велеумни племић Дон Кихот од Манче. Књ. 1 и 2 (превео Ђорђе Поповић). Београд: Гутенбергова галаксија. [Servantes, M. de (1999). Veleumni plemić Don Kihot od Manče. Knj. 1 i 2 (preveo Đorđe Popović). Beograd: Gutenbergova galaksija.]

Српски језик и књижевност, I разред, приступљено 20. 2. 2016. [Srpski jezik i književnost, I razred, pristupljeno 20. 2. 2016.] URL: <http://www.zuov. 
gov.rs/dokumenta/CRPU/Programi\%20za\%20gimnaziju\%20PDF/01\%20 srpski\%20jezik\%20i\%20knjizevnost.pdf>

Штанцл, Ф. (1987). Типичне форме романа. Нови Сад: Књижевна заједница Новог Сада. [Štancl, F. (1987). Tipične forme romana. Novi Sad: Književna zajednica Novog Sada.]

Auerbah, E. (1978). Mimesis: prikazivanje stvarnosti u zapadnoj književnosti. Beograd: Nolit.

Bazin, G. (1975). Barok i rokoko. Beograd: Jugoslavija.

Bahtin, M. (1978). Stvaralaštvo Fransoa Rablea i narodna kultura srednjeg veka i renesanse. Beograd: Nolit.

Bahtin, M. (1989). O romanu. Beograd: Nolit.

Božović, R. (1977). Uvođenje učenika srednje škole u svijet romana. Sarajevo: IGKRO „Svjetlost“" - OOUR Zavod za udžbenike.

Brenan, Dž. (1970). Španska književnost. Beograd: Nolit.

Cascardi, A. (1987). "Perspectivism and the conflict of values in Don Quijote". Romance Quarterly 34: 165-178.

Eko, U. (2001). Granice tumačenja. Beograd: Paideia.

Gracián, B. (1986). L'Acutezza e l'arte dell'Ingegno. Palermo.

Gracijan, V. (1997). Vrelo mudrosti ili pravila za život. Beograd: Ušće.

Peregrini, M. (1639). Delle acutezze, che altrimenti spiriti, vivezze, e concetti volgarmente si apellano... trattato. Genova.

RKT (1985). Rečnik književnih termina. Beograd: Nolit.

Rosandić, D. (2005). Metodika književnoga odgoja. Zagreb: Školska knjiga.

Tesauro, E. (1960). Il canochiale Aristotelico. Milano - Napoli.

Šklovski, V. ( 1969). Uskrsnuće riječi. Zagreb: Stvarnost.

Velázquez, Diego Rodríguez de Silva, Las Meniñas (1656). Приступљено 20.

2. 2016. URL: <https://www.museodelprado.es/coleccion/obra-de-arte/lasmeninas/9fdc7800-9ade-48b0-ab8b-edee94ea877f $>$

Velek, R. i O. Voren. (1991). Teorija književnosti. Beograd: Nolit. 
Dragoljub Perić

University of Novi Sad

Faculty of Philosophy

dragoljub.peric@ff.uns.ac.rs

\section{PERSPECTIVE AS AN INTEGRATING INTERPRETATION CENTRE - "DON QUIXOTE” BY MIGUEL DE CERVANTES IN THE MODEL OF INTEGRATED TEACHING}

\section{Summary}

This paper reveals a new model of teaching interpretation of the novel Don Quixote by Cervantes in the context of the integrative approach. The model proposed here, as a starting point and a factor of integration during the first teaching lesson/ unit on novel uses the perspective. After that, it continues with the research of the basic elements of baroque poetics and narrative form (author, storyteller, storytellersmediators, discovered manuscripts etc.). The main aim of the paper is to shed light on those elements of the structure and meaning of the novel whose cumulative interplay achieves intensification of artistic impressions. In other words, it demonstrates one aspect of teaching interpretation of this novel, according to the baroque poetics as dominant poetic discourse.

Key words: perspective, novel, poetics of baroque, factors of integration, teaching interpretation, narration.

Прилог 1

\section{Мигел де Сервантес, Дон Кихой}

(истраживачки задаци, 1. час)

Сервантес - живот и дело:

- Проучите биографију аутора и време у коме он ствара! Пронађите који су се елементи Сервантесове биографије нашли транспоновани у овом делу.

- Размислите зашто управо овај роман сматрамо првим модерним европским романом. У чему се састоји његов прекретнички карактер? У ком периоду је писан Дон Кихой? На шта то указује? Истражи сферу утицаја овог романа!

\section{Перспектива и поетика барока:}

- Обновити књижевноисторијска знања о поетици барока! Припремите се да аргументовано покажете којим елементима садржине и форме ово дело потврђује 
своје барокно исходиште! Размислите о природи интертекстовних веза овог дела с другим делима у контексту барокне поетике.

- Како из ваше перспективе изгледа Дон Кихот - његов поглед на свет, етички систем вредности, померена логика... Посредством којих елемената се постиже барокна перспектива у роману? Шта закључујете, које би биле особености барокне перспективе (повезати с Веласкезовим платном Младе племкиње - Las Meniñas) у погледу позиције уметника, начина представљања стварности, тенденције ка веродостојности...

Нарација у роману

- Каква је позиција наратора (приповедача) у роману? Ко све приповеда? У каквој функцији се појављује мултиплицирани лик наратора? Повежите сврховитост овог поступка с начелним поставкама поетике барока у погледу перспективе. Процените поступак увођења наратора - сведока! Какав је смисао манира нађеног рукописа? Размислите шта се постиже тиме што је поузданост приповедања доминантног наратора - Сид Амета - доведена у сумњу!

Литература за ученике:

Ауербах, Ерих, Мимесис, Нолит, Београд, 1978. [Auerbah, Erih, Mimesis, Nolit, Beograd, 1978.]

Павловић-Самуровић, Љиљана, “Дон Kихот” Мигела де Сервантеса, Завод за уџбенике и наставна средства, Београд, 1982. [Pavlović-Samurović, Ljiljana, "Don Kihot” Migela de Servantesa, Zavod za udžbenike i nastavna sredstva, Beograd, 1982.]

Попов, Јован, „Весници пародије: Бесни Орландо и Дон Кихот“, у: Двобој као књижевни мотив, Нови Сад: Академска књига, 88-105. [Popov, Jovan, „Vesnici parodije: Besni Orlando i Don Kihot“, u: Dvoboj kao književni motiv, Novi Sad: Akademska knjiga, 88-105.]

Šklovski, Viktor B. Uskrsnuće riječi, Stvarnost, Zagreb, 1969.

\section{Прилог 2}

Diego Rodríguez de Silva y Velázquez, Las Meniñas (1656). Приступљено 20. 2. 2016. [Diego Rodríguez de Silva y Velázquez, Las Meniñas (1656). Pristupljeno 20. 2. 2016.] URL: <https:/www.museodelprado.es/coleccion/obra-de-arte/lasmeninas/9fdc7800-9ade-48b0-ab8b-edee94ea877f $>$

Примљено: 22. 2. 2016. Прихваћено: 15. 5. 2016. 